\section{Mechanical Canopy Management Reduces Labor Costs and Maintains Fruit Composition in 'Cabernet Sauvignon' Grape Production}

\author{
S. Kaan Kurtural ${ }^{1,4}$, Geoffrey Dervishian ${ }^{1,2}$, and Robert L. Wample ${ }^{1,3}$
}

ADDITIONAL INDEX WORDs. dormant pruning, economics, shoot thinning, vineyard mechanization, warm climate viticulture

SUMMARY. Three canopy management methods, hand pruning (HP), mechanical prepruning with hand shoot thinning $(\mathrm{MP}+\mathrm{HT})$, and mechanical box-pruning with mechanical shoot thinning $(M P+M T)$, were applied with the objective of achieving similar and commercially marketable 'Cabernet sauvignon' grape (Vitis vinifera) yields while maintaining vine balance and comparing labor operations costs. Canopy management system labor operation cost estimates indicated a $62 \%$ and $80 \%$ labor savings with the $\mathrm{MP}+\mathrm{HT}$ and $\mathrm{MP}+\mathrm{MT}$ treatments, respectively when compared with HP. The total shoot density of the vines was unaffected by the treatments applied. However, the contribution of count shoots increased with the concomitant addition of mechanization to canopy management. All treatments achieved similar canopy architecture and microclimate. The treatments did not affect photosynthetically active radiation $(P A R)$ intercepted in the fruiting zone of canopy at veraison. All treatments had similar yield, total soluble solids (TSS), juice $\mathrm{pH}$, and titratable acidity (TA) at harvest. Berry skin total phenolics, anthocyanins, and tannins when measured at harvest were also similar among the treatments applied. All treatments tested were within acceptable Ravaz index limits of 5 to $10 \mathrm{lb} / \mathrm{lb}$. However, only MP+MT treatment reached a near optimum leaf area to fruit ratio of $1.2 \mathrm{~m}^{2} \cdot \mathrm{kg}^{-1}$ and pruning weight of $1.0 \mathrm{~kg} \cdot \mathrm{m}^{-1}$ for warm climate viticulture. The results of this study provide commercially acceptable mechanical canopy management options that may provide labor cost savings for winegrape growers in the San Joaquin Valley (SJV) of California.

$\mathrm{M}$ ore than $50 \%$ of the 3.6 million tons of winegrapes grown in California each year come from the SJV. Even though SJV grapes are a staple of California's wine industry, the increasing costs of labor present an economic risk for SJV winegrape vineyards. The cash market price for commercially acceptable winegrapes in Crush District 13 of California averaged $\$ 279.97 /$ ton (California Department of Food and Agriculture, 2012) with an average yield of 14.7 tons/acre, while total operating costs were $\$ 5007.00 /$ acre (Verdagaal et al., 2008). Therefore, winegrape growers are looking for

The authors acknowledge the California Agricultural Research Initiative, the Bronco Wine Company Viticulture Research Chair Trust Funds, and Oxbo International Corp. for partial funding during the execution of this project.

Mention of a trademark, proprietary product, or a vendor does not constitute a guarantee or warranty of the product by the California State University.

${ }^{1}$ Department of Viticulture and Enology, California State University, 2360 E. Barstow Avenue M/S, Fresno, CA 93740

${ }^{2}$ Research Associate

${ }^{3}$ Professor Emeritus, current address: 5596 N. Wright Ave, Clovis, CA 93619

${ }^{4}$ Corresponding author. E-mail: kkurtural@csufresno.edu. ways to reduce their labor costs, while maintaining yield and fruit quality parameters as demanded by winery contracts.

With narrow profit margins, the majority of the growers do not apply the principles of canopy management because of cost and time constraints (Terry and Kurtural, 2011). To remain profitable, growers tend to retain too many nodes during dormant pruning, resulting in out-of-balance vines with less than desirable fruit quality at the farm gate. Many growers preprune their vines with a mechanical prepruner to a bearing surface height of 8 inches $(\approx 250 \%$ of the nodes required by balanced pruning) and return to adjust shoot numbers at Eichhorn-Lorenz (E-L) growth stages 17 to 19 (Coombe, 1995). However, adjusting shoot numbers manually is expensive and requires rigorous crop estimation. The practice of mechanical prepruning and manual shoot removal leads to unbalanced vines because of time constraints to adjust the shoot numbers. This has become a greater problem as the labor supply declined. Unbalanced vines tend to develop large leaf canopies with a high water demand and an undesirable microclimate leading to a lower proportion of fruitful buds in subsequent seasons and fruit of inferior quality and a lower price. It has previously been shown that vine balance can be achieved in 'Syrah' (Vitis vinifera) grapevine grown in the SJV when they were mechanically boxpruned to a 4 -inch hedge and shoots thinned to a density of seven count shoots per foot of row, and irrigation was reduced to $50 \%$ of daily evapotranspiration (ETo) between fruit set and veraison (Terry and Kurtural, 2011). Bates and Morris (2009) recently reported a $56 \%$ to $80 \%$ per acre decrease in labor costs for 'Concord' grapevine (Vitis labrusca) when mechanical canopy management was used compared with traditional HP to produce a marketable crop.

A key component of the efficient use of the mechanical canopy management is to achieve balanced

\begin{tabular}{|c|c|c|c|}
\hline $\begin{array}{l}\text { Units } \\
\text { To convert U.S. to SI, } \\
\text { multiply by }\end{array}$ & U.S. unit & SI unit & $\begin{array}{l}\text { To convert SI to U.S., } \\
\text { multiply by }\end{array}$ \\
\hline 0.4047 & $\operatorname{acre}(\mathrm{s})$ & ha & 2.4711 \\
\hline 0.1 & $\operatorname{bar}(s)$ & $\mathrm{MPa}$ & 10 \\
\hline 29.5735 & $\mathrm{floz}$ & $\mathrm{mL}$ & 0.0338 \\
\hline 0.3048 & $\mathrm{ft}$ & $\mathrm{m}$ & 3.2808 \\
\hline 0.0929 & $\mathrm{ft}^{2}$ & $\mathrm{~m}^{2}$ & 10.7639 \\
\hline 0.2048 & $\mathrm{ft}^{2} / \mathrm{lb}$ & $\mathrm{m}^{2} \cdot \mathrm{kg}^{-1}$ & 4.8824 \\
\hline 3.7854 & gal & $\mathrm{L}$ & 0.2642 \\
\hline 2.54 & inch(es) & $\mathrm{cm}$ & 0.3937 \\
\hline 25.4 & inch(es) & $\mathrm{mm}$ & 0.0394 \\
\hline 2.54 & inch $^{2}$ /inch & $\mathrm{cm}^{2} \cdot \mathrm{cm}^{-1}$ & 0.3937 \\
\hline 0.4536 & $\mathrm{lb}$ & $\mathrm{kg}$ & 2.2046 \\
\hline 1.1209 & $\mathrm{lb} / \mathrm{acre}$ & $\mathrm{kg} \cdot \mathrm{ha}^{-1}$ & 0.8922 \\
\hline 1.4882 & $\mathrm{lb} / \mathrm{ft}$ & $\mathrm{kg} \cdot \mathrm{m}^{-1}$ & 0.6720 \\
\hline 0.1 & mbar(s) & $\mathrm{kPa}$ & 10 \\
\hline 28.3495 & $\mathrm{Oz}$ & g & 0.0353 \\
\hline$\left({ }^{\circ} \mathrm{F}-32\right) \div 1.8$ & ${ }^{\circ} \mathrm{F}$ & ${ }^{\circ} \mathrm{C}$ & $\left(1.8 \times{ }^{\circ} \mathrm{C}\right)+32$ \\
\hline
\end{tabular}


cropping along with a favorable canopy microclimate (Morris, 2007; Terry and Kurtural, 2011). Balance in vineyards can be measured with the Ravaz index. The Ravaz index is not a direct measurement but a ratio between vegetative and reproductive measurements expressed as crop yield per dormant pruning weight with optimum values between 5 and 10 (Kliewer and Dokoozlian, 2005). Balanced cropping aims to achieve equilibrium between vegetative and reproductive growth of the grapevine, and thus ensures sustainable vineyard production. Canopy management, whether applied by conventional or mechanical methods, may include the following practices: 1) dormant pruning, 2) shoot thinning, 3 ) shoot positioning, 4) cluster thinning, 5) leaf removal, and 6) hedging/ skirting. The effects of various canopy management practices are varied depending on the macroclimate, cultivar, and irrigation requirement of a vineyard. The effects may include reduced vegetative growth (Smart, 1985,1988 ), a favorable light regime in the defined fruit zone (Dokoozlian and Kliewer, 1995; Gladstone and Dokoozlian, 2003), enhanced fruit composition (Kurtural et al., 2006; Petrie and Clingeleffer, 2006; Smart, 1988; Terry and Kurtural, 2011), and balanced vines for sustained commercial production (Morris, 2007; Reynolds and Wardle, 1993; Terry and Kurtural, 2011).

While there have been numerous attempts to quantify the labor costs associated with mechanical canopy management in California, there are no published reports of replicated trials in this area. The objective of this study was to compare the viticulture and economic characteristics of traditional HP, mechanical prepruning plus manual shoot thinning, and mechanical box-pruning plus mechanical shoot thinning in the SJV of California. The measurements used to quantify the effects of these three canopy management practices included canopy architecture and microclimate, yield components, fruit composition, and labor costs.

\section{Materials and methods}

VINEYARD AND SITE DESCRIPTION. This study was conducted from 2009 to 2010 at a commercial vineyard planted with 'Cabernet Sauvignon
07' ( $V$. vinifera) grapevine on 'Freedom' (a complex cross with $28 \% \mathrm{~V}$. vinifera) rootstock at $7 \times 12 \mathrm{ft}($ vine $\times$ row) spacing in east-west oriented rows. The research site was located in Fresno County, CA (lat. $36.49^{\circ} \mathrm{N}$, long. $119.44^{\circ} \mathrm{W}, 102 \mathrm{~m}$ absolute elevation) and was planted in 1999 on San Joaquin loam soil [a fine, mixed, active Abruptic Durixeralf (U.S. Department of Agriculture, 2011)]. The vines were trained to a bilateral cordon at $\mathbf{5 4}$ inches above vineyard floor with two foliage support wires at 62 inches on a 24 inch t-top. The vineyard was drip irrigated with pressure-compensating emitters spaced at 38 inches delivering $0.5 \mathrm{gal} / \mathrm{h}$ per vine. The vines were supplied with $8 \mathrm{lb} /$ acre of nitrogen in each year. Irrigation was managed in the top 36 inches of the soil profile, and precipitation in winter and spring (8.24 and 16.49 inches in 2009 and 2010 , respectively) was insufficient to fill the soil profile by budbreak in both years. The root zone was irrigated beginning in the third week of March based on a crop coefficient $(K \mathrm{c})$ of 0.2 and $80 \%$ of the daily ETo values for which were obtained from the California Irrigation Management Information System station in Fresno, CA. Irrigation was interrupted before bloom and the soil was allowed to dry down until fruit set when midday leaf water potential was below -12 bars. The midday leaf water potential was measured at solar noon every 7-d cycle on four fully expanded sun leaves per data vine with a Scholandertype pressure bomb (model 610 Pressure Chamber Instrument; PMS Instrument Co., Corvallis, OR). After fruit set, $50 \%$ of daily ETo was applied until veraison, where $K c$ was calculated to be 0.3 at fruit set to 0.8 at veraison. Irrigation was triggered when midday leaf water potential was below -14 bars between fruit set and veraison. Starting at veraison, irrigation was applied at $80 \%$ of daily ETo with a $K \mathrm{c}$ of 0.8 , and irrigation was trigged when midday leaf water potential was below -12 bars. Pests were managed using an integrated pest management program according to University of California guidelines (Flaherty et al., 1992). The experiment was set up with three canopy management methods consisting of four replications of each treatment in a randomized complete block design.
Each replicated experimental unit consisted of 96 vines, 16 of which were sampled. The same vines were used for all treatments in all years of the study.

Treatments applied. Three canopy management methods with different levels of mechanical intervention were applied with the objective of achieving similar and commercially marketable grape yields. The vineyard was under contract to produce 6.5 tons/acre at $24 \%$ TSS in 2008 and 2009 , and 7.5 tons/acre at $25 \%$ TSS in 2010. The following treatments were imposed starting in 2008 and data collection commenced in 2009 to allow the vines to adjust to mechanical manipulation. HP treatment consisted of the conventional manual spur pruning with 36 to 40 buds per vine with no further canopy manipulation. Hand labor pass was conducted to tie any loose cordons and remove debris from the trellis. The mechanical prepruning with hand thinning treatment consisted of mechanically pruning the previous year's canes to a bearing surface height of 8 inches in the dormant season with a 24 -inch double, sprawlpruner head (model 63700; Oxbo International, Kingsburg, CA) mounted onto tool carrier (model 1210, Oxbo International). Hand labor pass performed to remove any outlier shoots missed by the implement around posts and remove any debris in the canopy. At E-L growth stage 17, crop level was estimated as described by Kurtural and O'Daniel (2008), and the bearing surface was then manually adjusted to $\approx 85$ shoots/vine to attain the same crop level as HP. The mechanical pruning with mechanical thinning treatment consisted of mechanically box-pruning the previous year's canes to a bearing surface height of 4 inches in the dormant season with the above referenced implement. A hand labor pass was performed to remove any outlier shoots missed by the mechanical pruner and remove any debris in the canopy. At E-L growth stage 17, crop level was estimated and the bearing surface was mechanically adjusted to $\approx 85$ shoots per vine with a rotarypaddle shoot thinner with a rotary brush attachment (model 62731, Oxbo International) to achieve the same crop level as HP.

CANOPY AND VINE MEASUREMENTS. Shoot numbers were measured 2 weeks after bud burst and after the 
application of canopy management treatments as described elsewhere (Terry and Kurtural, 2011). Total shoots per vine were counted by the addition of count shoots (borne from count positions $>5 \mathrm{~mm}$ distal to the base of the bearing surface) and noncount shoots (borne from noncount positions $<5 \mathrm{~mm}$ distal to the base of the bearing surface and secondary shoots). Indicators of canopy architecture measurements such as distance between shoots, leaf layers, and leafiness index were measured as described by Smart (1985).

A ceptometer (AccuPAR-80; Decagon Devices, Pullman, WA) was placed directly above cordon, within the fruiting zone parallel to the vine row at the head of each vine. There were four measurements taken with the ceptometer from 16 vines per experimental unit. Ambient readings were taken at a height of $2 \mathrm{ft}$ above the canopy surface. The remaining three measurements were taken within the fruiting zone at the head of the vine. Measurements were taken at 1200 growing degree days at midday with $P A R$ values ranging $\approx 1900$ to $2200 \mu \mathrm{mol} \cdot \mathrm{m}^{-2} \cdot \mathrm{s}^{-1}$. The three fruiting zone $P A R$ measurements were combined and expressed as the percentage of total ambient $P A R$ measured at midday.

Leaf area per shoot and the canopy leaf area of the vine were determined at $50 \%$ veraison from 16 vines per experimental unit. Four shoots from the north and south sides of the canopy per vine for a total of eight shoots were sampled at random and stored at $36{ }^{\circ} \mathrm{F}$ at $98 \%$ humidity until measured. Each shoot was separated into main and lateral axes. The number of leaves per axis was counted, and leaf area was measured with a leaf area meter (LI-3000; LI-COR, Lincoln, $\mathrm{NE}$ ). The canopy leaf area per vine was then determined as described by Keller et al. (2008).

YIELD, FRUIT COMPOSITION, AND RAVAZ INDEX ASSESSMENT. Fruit yield and cluster numbers for each treatment were measured by hand harvesting 16 vines from each experimental unit. During both years, yield was examined for distinction between marketable and unmarketable fruit (fruit displaying $>30 \%$ disease damage or insect herbivory). However, in both years, there was no unmarketable fruit. All treatments were harvested on the same day. Average cluster weight was calculated by dividing fruit yield per vine by the number of clusters harvested per vine. Ravaz index was calculated by dividing the yield per vine by the dormant pruning weight per vine and is expressed as pounds per pounds. Leaf area to fruit ratio was calculated by dividing the leaf area of each vine by the yield per vine and is expressed as square meters per kilogram.

Fruit composition was measured at harvest. A random 100-berry sample was collected from 16 vines from each experimental unit, placed in polyethylene bags, stored on ice and analyzed within $24 \mathrm{~h}$. Before analysis, the 100-berry sample was weighed and average berry mass was determined. The samples were then crushed by hand and the juice was placed in 100-mL beakers. A 5-mL sample was used to determine the percent TSS using a digital refractometer (PAL-1; Atago Co., Tokyo, Japan). Juice pH was determined with a glass electrode and a $\mathrm{pH}$ meter (model XL15; Fisher Scientific, Pittsburgh, PA). TA of each sample was determined by titrating to $\mathrm{pH} 8.2$ with $0.1 \mathrm{~N}$ sodium hydroxide using an endpoint titrator (model DL 15; Mettler-Toledo International, Columbus, $\mathrm{OH}$ ) and expressed as milligrams per liter.

Samples of 20 random berries at harvest for each treatment were used to measure anthocyanins, total iron reactive phenolics, and tannins. Berry skins were removed from the pulp by hand, rinsed with tap water followed by distilled water, and blotted dry with paper towels. The skins were then extracted in $30 \mathrm{~mL}$ $50 \% \mathrm{v} / \mathrm{v}$ acetone solution in darkness for $24 \mathrm{~h}$. Acetone was removed from samples using a rotary evaporator at 170 mbar at $30^{\circ} \mathrm{C}$. Each sample was then diluted with deionized water to a final volume of $25 \mathrm{~mL}$. Total phenols, tannins, and monomeric anthocyanins were quantified spectrophotometrically (Lambda 25 ultraviolet/VIS; PerkinElmer, Waltham, MA). Tannin content was assayed using protein precipitation (bovine serum albumin; Sigma-Aldrich, St. Louis, MO), ferric chloride reagent (Fisher Scientific), and buffer solutions (Hagerman and Butler, 1978; Harbertson et al., 2003) and quantified from a standard curve for catechin (catechin hydrate, Sigma-Aldrich).
Total phenolic content was determined following a Folin-Ciocalteu microscale method (Waterhouse, 2002) using Folin-Ciocalteu reagent (MP Biomedicals, Solon, $\mathrm{OH}$ ) and quantified from a standard curve for gallic acid (Sigma-Aldrich). Total monomeric anthocyanin content was measured by $\mathrm{pH}$ differential (Giusti and Wrolstad, 2001) and quantified based on molar absorptivity and molecular weight of malvidin3-glucoside (Indofine Chemical, Hillsborough, NJ).

Cost calculations. All labor, benefit, and fuel rates used in cost calculations were obtained from Verdagaal et al. (2008). The time to apply the HP treatment and the follow-up labor was measured by timing the same laborer in 2009 and 2010 in each treatment replicate. The time to accomplish these tasks was then divided by the number of vines in the four treatment replicates measured, then the labor hours and cost per acre were calculated by multiplying the time and cost per vine by the number of vines per acre. Cost calculations in the MP+HT treatment were done as follows. The time to accomplish the mechanical prepruning and equipment maintenance were measured by timing the same operator in 2009 and 2010 in each treatment replicate. The manual follow-up labor was measured in each treatment replicate by timing the same laborer in 2009 and 2010 . The time it took to estimate the crop was also measured in each treatment replicate in both years. The same laborer was used in both years to conduct the hand shoot thinning task and was timed for each treatment replicate. A cost per vine to accomplish each task was calculated, multiplied by the appropriate labor and benefit rate, and labor cost per acre was calculated by multiplying the resultant costs by the number of vines per acre. The amount of hours the mechanical prepruner operated was multiplied by the fuel cost to calculate the fuel cost. The labor and fuel costs were added to calculate the cost per acre. Cost calculations in the MP+MT treatment were calculated using the same methods as MP+HT with the exception of hand shoot thinning labor being replaced with the mechanical shoot thinning labor. A thinning fuel cost was also added to calculate the cost per acre. 
Data ANALYSIs. Statistical analyses were conducted using SAS (version 9.2; SAS Institute, Cary, NC). Data were tested for homogeneity of variance using the Levene's test (Levene, 1960) and were then subjected to two-way (management method $\times$ year) analysis of variance (ANOVA) using the general linear procedure of SAS to conduct the F test. Management methods were also analyzed as a one-way ANOVA for each year, and post hoc mean comparisons were conducted using the Tukey's honestly significant difference test. The effects of year were also analyzed as a oneway ANOVA for each management method.

\section{Results and discussion}

SHOOT, CLUSTER COUNTS, CANOPY ARCHITECTURE, AND MICROCLIMATE. The canopy management methods employed affected the number of count shoots retained on the vines in 2009 and 2010 (Table 1). In 2009, the MP+MT treatment had $49 \%$ more count shoots than the HP treatment. In 2010 , the MP+MT had $61 \%$ and $50 \%$ more count shoots than the HP and $\mathrm{MP}+\mathrm{HT}$ treatments, respectively. The difference in the number of count shoots can be attributed to the selective pruning process with
$\mathrm{HP}$, compared with the nonselective hedge pruning accomplished with the MP treatments. The canopy management treatments did not affect the number of noncount shoots in 2009 or 2010. The count and noncount cluster numbers were unaffected by the canopy management treatments in 2009. In 2010, the MP+MT had $64 \%$ and $53 \%$ more count clusters per vine than the $\mathrm{HP}$ and $\mathrm{MP}+\mathrm{HT}$ treatments, respectively. There was no effect of canopy management treatments on the number of noncount clusters in either year. The total number of shoots retained on the vines was unaffected by the treatments applied in 2009. However, in 2010, the $\mathrm{MP}+\mathrm{MT}$ treatment had 32\% more total shoots than the HP treatment. The total number of clusters per vine was affected in each year of the study. In 2009, the MP+MT treatment had $27 \%$ more clusters per vine than the HP treatment (Table 1). In 2010, the $\mathrm{MP}+\mathrm{MT}$ treatment had $54 \%$ and $46 \%$ more total clusters per vine than the $\mathrm{HP}$ and $\mathrm{MP}+\mathrm{HT}$ treatments, respectively. In similar trials that were conducted for more than 2 years (Bates and Morris, 2009), cluster numbers harvested per vine was unaffected by experimental year only if manual crop thinning was applied.
There was no effect of treatments applied on canopy architecture or microclimate variables measured in 2009 or 2010 (Table 2). However, there was an effect of year on the canopy leaf area. The HP and MP+HT treatments saw a $55 \%$ and $58 \%$ increase in canopy leaf area from 2009 to 2010 , respectively (Table 2). Mechanical canopy management methods were effective in both years in attaining similar canopy architecture, microclimate, and size. Although, the distance between shoots was similar to the ones reported elsewhere, the leafiness index was slightly higher (Terry and Kurtural, 2011.) This was attributed to the smaller leaf blade of the cultivar tested in this trial and the wide row spacing $(>10 \mathrm{ft})$ used in the SJV (Smart, 1985). The leaf layer numbers achieved were slightly higher than the three to four leaf layers recommended for warm climate viticulture but were similar for all treatments applied as prescribed by the study design (Smart, 1985; Terry and Kurtural, 2011). The treatments applied did not affect the amount of $P A R$ measured in the fruit zone of the canopy in either year of the study and were similar to the ranges reported for sprawling type canopies (Dokoozlian and Kliewer, 1995; Table 2). The canopy leaf area was

Table 1. Effects of conventional and mechanical canopy management on average shoot and clusters numbers per vine of 'Cabernet Sauvignon' grapevine in 2009 and 2010 post canopy management applications in Fresno, CA $(n=4)$.

\begin{tabular}{|c|c|c|c|c|c|c|}
\hline Management method $^{\mathrm{z}}$ & $\begin{array}{l}\text { Count shoots } \\
(\text { no./vine })^{\mathrm{y}}\end{array}$ & $\begin{array}{c}\text { Noncount } \\
\text { shoots } \\
\text { (no./vine) }^{\mathrm{y}}\end{array}$ & $\begin{array}{l}\text { Count clusters } \\
(\text { no./vine })^{\mathrm{x}}\end{array}$ & $\begin{array}{c}\text { Noncount } \\
\text { clusters } \\
\text { (no./vine) }\end{array}$ & $\begin{array}{c}\text { Total } \\
\text { shoots } \\
\text { (no./vine) }\end{array}$ & $\begin{array}{c}\text { Total } \\
\text { clusters } \\
\text { (no./vine) }\end{array}$ \\
\hline \multicolumn{7}{|c|}{2009} \\
\hline $\mathrm{HP}$ & $20 b^{w}$ & 67 & 27 & 36 & 87 & $62 \mathrm{~b}$ \\
\hline $\mathrm{MP}+\mathrm{HT}$ & $24 \mathrm{ab}$ & 62 & 37 & 27 & 86 & $64 \mathrm{ab}$ \\
\hline $\mathrm{MP}+\mathrm{MT}$ & $39 \mathrm{a}$ & 57 & 54 & 32 & 96 & $85 \mathrm{a}$ \\
\hline \multicolumn{7}{|c|}{2010} \\
\hline $\mathrm{HP}$ & $22 \mathrm{~b}$ & 43 & $24 \mathrm{~b}$ & 14 & $66 \mathrm{~b}$ & $39 \mathrm{~b}$ \\
\hline $\mathrm{MP}+\mathrm{HT}$ & $29 \mathrm{~b}$ & 51 & $31 \mathrm{~b}$ & 15 & $81 \mathrm{ab}$ & $46 \mathrm{~b}$ \\
\hline $\mathrm{MP}+\mathrm{MT}$ & $57 \mathrm{a}$ & 41 & $66 \mathrm{a}$ & 19 & 98 a & $85 \mathrm{a}$ \\
\hline$P>\mathrm{F}$ & 0.0004 & 0.1055 & 0.0001 & 0.1103 & 0.0217 & 0.0001 \\
\hline $\operatorname{Year}(P>\mathrm{F})$ & 0.7845 & 0.6124 & 0.1281 & 0.3574 & 0.6174 & 0.2147 \\
\hline
\end{tabular}

method $(P>\mathrm{F})$

${ }^{2} \mathrm{HP}=$ hand pruned to $36-40$ buds, MP+HT = mechanically prepruned to an 8-inch $(20.4 \mathrm{~cm})$ bearing surface, hand shoot thinning conducted at Eichhorn-Lorenz scale (Coombe, 1995) stage 17 to retain similar number of shoots as HP, MP+MT = mechanically box-pruned to a 4 -inch (10.2 cm) bearing surface, mechanical shoot thinning conducted at Eichhorn-Lorenz scale stage 17 to retain similar number of shoots as HP.

${ }^{\mathrm{y}}$ Count shoots $=$ shoots borne from count positions $>5 \mathrm{~mm}(0.2 \mathrm{inch})$ distal to the base of the bearing surface, noncount shoots $=$ shoots borne from noncount positions $<5 \mathrm{~mm}$ distal to the base of the bearing surface, total shoots = count shoots + noncount shoots.

${ }^{\mathrm{x}}$ Count clusters $=$ clusters borne on positions from count shoots, noncount clusters $=$ clusters borne on positions from noncount shoots, total clusters $=$ count clusters + noncount clusters.

"Values with different letter designation represent significant mean separation among management methods according to Tukey's honestly significant difference test at $P \leq 0.05$. 
unaffected by the treatments applied (Table 2). However, canopy leaf area of vines treated $\mathrm{HP}$ and $\mathrm{MP}+\mathrm{HT}$ increased by $55 \%$ from 2009 to 2010 . The canopy leaf area achieved by the applied treatments was similar to the recommended levels in literature for red winegrapes within the same growing region (Terry and Kurtural, 2011).

Yield COMPONENTS, RAVAZ INDEX, PRUNING WEIGHT, AND LEAF AREA TO FRUIT RATIO. The treatments applied were successful in attaining similar crop levels in both years of the study. In 2009, the number of clusters harvested was slightly higher with the MP+MT and HP treatments compared with $\mathrm{MP}+\mathrm{HT}$ (Table 3). However, the same response was not evident in 2010. Berry and cluster weight were also unaffected by the treatments applied (Table 3). It was expected that berry size at harvest would be smaller with treatments that received mechanical box-pruning (Zabadal et al., 2002) compared with the HP treatment. However, there was no difference in berry weights with the treatments applied. It was expected that there would be some berry compensation by shoot thinning at E-L growth stage 17 compared with the HP treatment (Terry and Kurtural, 2011). Although there was some indication that berry size was increasing with the $\mathrm{MP}+\mathrm{MT}$ and $\mathrm{MP}+\mathrm{HT}$ in 2009 , there was no statistical evidence of berry compensation in either year of the study. Yield was unaffected by the treatments applied in either year (Table 3 ). The Ravaz index, pruning weight, and leaf area to fruit ratio were also unaffected by the treatments applied (Table 3). A Ravaz index value between 5 and 10 is required for ideal levels of TSS accumulation and berry coloration in winegrapes (Kliewer and Dokoozlian, 2005). All treatments achieved a Ravaz index within this range in both years of the study. However, integrating mechanical manipulation to canopy management either by $\mathrm{MP}+\mathrm{HT}$ or MP+MT slightly elevated the Ravaz index compared with the grapevines that received the HP treatment. Pruning weight values of 0.3 to $0.6 \mathrm{~kg} \cdot \mathrm{m}^{-1}$ are generally considered to be in the optimal range for cool climate growing regions (Kurtural et al., 2006; Smart and Robinson, 1991). However, the data presented in this study is in concert with reports from warm climate grape growing regions (Dokoozlian and Kliewer, 1995; Kliewer and Dokoozlian, 2005; Terry and Kurtural, 2011). Pruning weight values up to $1.0 \mathrm{~kg} \cdot \mathrm{m}^{-1}$ for red winegrape cultivars are indeed capable of producing high-quality fruit without loss of productivity. The MP+MT treatment resulted in values slightly less than the optimum pruning weight value of $1 \mathrm{~kg} \cdot \mathrm{m}^{-1}$. Leaf area to fruit ratio values between 0.8 and $1.2 \mathrm{~m}^{2} \cdot \mathrm{kg}^{-1}$ are considered optimal for winegrape production (Kliewer and Dokoozlian, 2005). Although there was no statistical separation of treatments in either year, experimental year had an effect on the leaf area to fruit ratio (Table 3 ). The $\mathrm{MP}+\mathrm{MT}$ treatment was close to achieving the optimum range in leaf area to fruit ratio in both years of the study, where the other treatments indicated not enough leaf area for the amount of fruit carried in 2009 for the HP, and too much leaf area for the amount of fruit carried for $\mathrm{HP}$ and $\mathrm{MP}+\mathrm{HP}$ in 2010.

FRUIT COMPOSITION AND BERRY SKIN PHENOLICS. There was no effect of treatments applied on TSS of 'Cabernet Sauvignon' when measured at harvest in either year of the study. In 2009 , the juice $\mathrm{pH}$ was unaffected by treatments applied (Table 4). However, in 2010, the HP treatment increased juice $\mathrm{pH}$ by $4 \%$ compared with $\mathrm{MP}+\mathrm{HT}$ and $\mathrm{MP}+\mathrm{MT}$ treatments. The TA of 'Cabernet Sauvignon' was unaffected by the treatments applied in either year of the study. However, in 2010 , the TA was considerably higher for all treatments compared with 2009. This was attributed to climatic factors that resulted in higher canopy leaf area in 2010. General response of TA was to increase with closer shoot spacing along the cordon and increased canopy leaf area (Smart and Robinson, 1991). There was no effect of treatments applied on the berry skin phenolics of 'Cabernet Sauvignon' in

Table 2. Effects of conventional and mechanical canopy management on average canopy architecture and microclimate values of 'Cabernet Sauvignon' grapevine in 2009 and 2010 in Fresno, CA $(n=4)$.

\begin{tabular}{|c|c|c|c|c|c|}
\hline Management method ${ }^{\mathrm{z}}$ & $\begin{array}{l}\text { Leafiness index } \\
\left(\mathrm{cm}^{2} \cdot \mathrm{cm}^{-1}\right)^{\mathrm{y}}\end{array}$ & $\begin{array}{c}\text { Distance between } \\
\text { shoots }(\mathrm{cm})^{\mathrm{y}}\end{array}$ & $\begin{array}{c}\text { Leaf layers } \\
\text { (no.) }\end{array}$ & $\begin{array}{c}P A R \text { in the } \\
\text { fruit zone }(\%)^{\mathrm{x}}\end{array}$ & $\begin{array}{c}\text { Canopy leaf } \\
\text { area }\left(\mathrm{m}^{2}\right)^{\mathrm{y}} \\
\end{array}$ \\
\hline \multicolumn{6}{|c|}{2009} \\
\hline $\mathrm{MP}+\mathrm{HT}$ & 23.4 & 4.4 & 5.3 & 18 & 8.2 \\
\hline $\mathrm{MP}+\mathrm{MT}$ & 20.1 & 3.8 & 5.5 & 19 & 9.6 \\
\hline$P>\mathrm{F}$ & 0.1906 & 0.1644 & 0.4147 & 0.7337 & 0.1870 \\
\hline
\end{tabular}

\begin{tabular}{|c|c|c|c|c|c|}
\hline \multicolumn{6}{|c|}{2010} \\
\hline $\mathrm{MP}+\mathrm{MT}$ & 22.6 & 4.2 & 5.5 & 19 & 12.4 \\
\hline $\operatorname{Year}(P>\mathrm{F})$ & 0.4957 & 0.5419 & 0.5741 & 0.8751 & 0.0289 \\
\hline $\begin{array}{c}\text { Year } \times \text { management } \\
\text { method }(P>\mathrm{F})\end{array}$ & 0.1954 & 0.3654 & 0.1385 & 0.9457 & 0.0001 \\
\hline
\end{tabular}


Table 3. Effects of conventional and mechanical canopy management on average yield components, crop load and leaf area to fruit ratio of 'Cabernet Sauvignon' grapevine in 2009 and 2010 in Fresno, CA $(n=4)$.

\begin{tabular}{|c|c|c|c|c|c|c|c|}
\hline $\begin{array}{l}\text { Management } \\
\operatorname{method}^{\mathrm{z}}\end{array}$ & $\begin{array}{c}\text { Clusters harvested } \\
\text { (no./vine) }\end{array}$ & $\begin{array}{l}\text { Cluster wt } \\
(\mathrm{g})^{\mathrm{y}}\end{array}$ & $\begin{array}{l}\text { Berry wt } \\
(\mathrm{g})\end{array}$ & $\begin{array}{c}\text { Yield } \\
{\text { (tons } / \text { acre })^{y}}\end{array}$ & $\begin{array}{l}\text { Ravaz index } \\
(1 \mathrm{l} / \mathrm{lb})^{\mathrm{x}}\end{array}$ & $\begin{array}{l}\text { Pruning wt } \\
\left(\mathrm{kg} \cdot \mathrm{m}^{-1}\right)^{\mathrm{y}}\end{array}$ & $\begin{array}{l}\text { Leaf area:fruit } \\
\left(\mathrm{m}^{2} \cdot \mathrm{kg}^{-1}\right)^{\mathrm{y}} \\
\end{array}$ \\
\hline \multicolumn{8}{|c|}{2009} \\
\hline $\mathrm{HP}$ & $119 \mathrm{ab}^{\mathrm{w}}$ & 84.5 & 1.15 & 6.3 & 6.4 & 0.75 & 0.59 \\
\hline $\mathrm{MP}+\mathrm{MT}$ & $127 \mathrm{a}$ & 92.5 & 1.36 & 7.4 & 7.7 & 0.72 & 0.84 \\
\hline$P>\mathrm{F}$ & 0.0213 & 0.5245 & 0.1163 & 0.0534 & 0.2171 & 0.1441 & 0.3714 \\
\hline $\mathrm{HP}$ & 121 & 86.9 & 1.07 & 6.1 & 5.0 & 0.86 & 1.35 \\
\hline $\mathrm{MP}+\mathrm{HT}$ & 139 & 89.3 & 1.09 & 7.8 & 7.0 & 0.82 & 1.70 \\
\hline $\mathrm{MP}+\mathrm{MT}$ & 142 & 84.3 & 1.11 & 7.5 & 5.9 & 0.92 & 1.08 \\
\hline$P>\mathrm{F}$ & 0.6668 & 0.9396 & 0.8117 & 0.3669 & 0.3184 & 0.4890 & 0.4151 \\
\hline Year $(P>\mathrm{F})$ & 0.8124 & 0.6217 & 0.1854 & 0.0781 & 0.6387 & 0.0981 & 0.0002 \\
\hline $\begin{array}{c}\text { Year } \times \text { management } \\
\text { method }(P>\mathrm{F})\end{array}$ & 0.0124 & 0.7219 & 0.0841 & 0.0671 & 0.6714 & 0.1573 & 0.0001 \\
\hline
\end{tabular}

Table 4. Effects of conventional and mechanical canopy management on average fruit composition of 'Cabernet Sauvingon' grapevine at harvest in 2009 and 2010 in Fresno, CA $(n=4)$.

\begin{tabular}{|c|c|c|c|c|c|c|}
\hline Management method $^{\mathrm{z}}$ & $\begin{array}{l}\text { TSS } \\
(\%)^{\mathrm{y}}\end{array}$ & $\begin{array}{c}\text { Juice } \\
\mathrm{pH}\end{array}$ & $\begin{array}{c}\text { TA } \\
\left(\mathrm{mg} \cdot \mathrm{L}^{-1}\right)^{\mathrm{x}}\end{array}$ & $\begin{array}{c}\text { Total } \\
\text { phenolics } \\
\left(\mu \mathrm{g} \cdot \mathrm{g}^{-1}\right)^{\mathrm{w}}\end{array}$ & $\begin{array}{c}\text { Anthocyanins } \\
\left(\mu \mathrm{g} \cdot \mathrm{g}^{-1}\right)\end{array}$ & $\begin{array}{l}\text { Tannins } \\
\left(\mu \mathrm{g} \cdot \mathrm{g}^{-1}\right) \\
\end{array}$ \\
\hline \multicolumn{7}{|c|}{2009} \\
\hline $\mathrm{HP}$ & 24.1 & 3.92 & 4.70 & 1248 & 302 & 357 \\
\hline $\mathrm{MP}+\mathrm{HT}$ & 24.3 & 3.83 & 5.12 & 1237 & 298 & 348 \\
\hline $\mathrm{MP}+\mathrm{MT}$ & 24.1 & 3.77 & 5.22 & 1208 & 291 & 371 \\
\hline \multicolumn{7}{|c|}{2010} \\
\hline $\mathrm{HP}$ & 25.6 & $3.87 \mathrm{a}^{\mathrm{v}}$ & 6.95 & 1191 & 297 & 341 \\
\hline $\mathrm{MP}+\mathrm{HT}$ & 25.6 & $3.73 \mathrm{~b}$ & 6.45 & 1201 & 281 & 345 \\
\hline $\mathrm{MP}+\mathrm{MT}$ & 25.5 & $3.74 \mathrm{~b}$ & 7.55 & 1197 & 292 & 361 \\
\hline$P>\mathrm{F}$ & 0.9629 & 0.0029 & 0.1537 & 0.3217 & 0.1447 & 0.7112 \\
\hline $\operatorname{Year}(P>\mathrm{F})$ & 0.0871 & 0.0504 & 0.0537 & 0.0914 & 0.4720 & 0.8744 \\
\hline
\end{tabular}

${ }^{2} \mathrm{HP}=$ hand pruned to $36-40$ buds, MP+HT = mechanically prepruned to an 8 -inch $(20.4 \mathrm{~cm})$ bearing surface, hand shoot thinning conducted at Eichhorn-Lorenz scale (Coombe, 1995) stage 17 to retain similar number of shoots as $\mathrm{HP}, \mathrm{MP}+\mathrm{MT}=$ mechanically box-pruned to a 4 -inch ( $10.2 \mathrm{~cm}$ ) bearing surface, mechanical shoot thinning conducted at Eichhorn-Lorenz scale stage 17 to retain similar number of shoots as HP.

TSS $=$ total soluble solids in juice.

${ }^{\mathrm{x}} \mathrm{TA}=$ titratable acidity measured as milligrams of tartaric acid per liter of juice; $1 \mathrm{mg} \cdot \mathrm{L}^{-1}=1 \mathrm{ppm}$.

${ }^{\mathrm{w}} 1 \mu \mathrm{g} \cdot \mathrm{g}^{-1}=1 \mathrm{ppm}$

"Values with different letter designation represent significant mean separation among management methods according to Tukey's honestly significant difference test at $P \leq 0.05$

either year of the study (Table 4 ). The anthocyanin, flavonol, and tannin profile of harvested fruit determines the color potential of a wine, and color is the main driver of perceived quality in red wines (Keller, 2010). In warm, semiarid growing regions such as the SJV, increased solar exposure because of canopy management by mechanical shoot thinning in the absence of excessive fruit heat gain has been shown to increase berry skin phenolics compared with mechanical box-pruning alone (Terry and Kurtural, 2011). In the current study, mechanically managed treatments, regardless of shoot thinning method employed, achieved the same berry skin phenolics compared with HP vines.

Cost COMPARISON. The labor costs for the three canopy management methods were analyzed as reported by Bates and Morris (2009). The HP treatment had the highest labor operation cost per acre. The $\mathrm{MP}+\mathrm{HP}$ reduced the labor operation cost per acre by $62 \%$ compared with HP treatment in the vineyard studied (Table 5). The MP+MT treatment reduced the labor operation cost per acre by $80 \%$ and $47 \%$ compared with $\mathrm{HP}$ and $\mathrm{MP}+\mathrm{HP}$ treatments, respectively, during the course of the study. 
Table 5. Labor cost comparison for conventional and mechanical canopy management of 'Cabernet Sauvignon' grapevine in Fresno, CA.

\begin{tabular}{|c|c|c|c|}
\hline \multirow{2}{*}{ Mangement method ${ }^{\mathrm{z}}$} & \multicolumn{3}{|c|}{ Cost calculations } \\
\hline & $(\$ / h)$ & $(\mathrm{h} / \text { acre })^{\mathrm{y}}$ & $(\$ / \text { acre })^{y}$ \\
\hline \multicolumn{4}{|l|}{$\mathrm{HP}$} \\
\hline HP labor & 8.50 & 28.4 & 241.40 \\
\hline HP follow-up & 8.50 & 7.3 & 62.05 \\
\hline Benefit rate & $33 \%$ & & 100.14 \\
\hline Total & & & 403.59 \\
\hline \multicolumn{4}{|l|}{$\mathrm{MP}+\mathrm{HT}$} \\
\hline Mechanical pruning labor & 12.00 & 1.85 & 22.20 \\
\hline Manual follow-up labor & 8.50 & 1.20 & 10.20 \\
\hline Crop estimation labor & 12.00 & 0.34 & 4.08 \\
\hline Hand shoot thinning labor & 8.50 & 8.43 & 71.66 \\
\hline Equipment maintenance labor & 12.00 & 0.24 & 2.88 \\
\hline Benefit rate & $33 \%$ & & 36.64 \\
\hline Pruning fuel & $\begin{array}{r}1.851 \\
\$ 4\end{array}$ & $\begin{array}{l}\times \mathrm{gal} / \mathrm{h} \times \\
\mathrm{l}\end{array}$ & 7.40 \\
\hline Total & & & 153.42 \\
\hline \multicolumn{4}{|l|}{$\mathrm{MP}+\mathrm{MT}$} \\
\hline Mechanical pruning labor & 12.00 & 1.85 & 22.20 \\
\hline Manual follow-up labor & 8.50 & 1.20 & 10.20 \\
\hline Mechanical crop estimation labor & 12.00 & 0.34 & 4.08 \\
\hline Mechanical crop thinning labor & 12.00 & 0.9 & 10.80 \\
\hline Equipment maintenance labor & 12.00 & 0.48 & 5.76 \\
\hline Benefit rate & $33 \%$ & & 17.50 \\
\hline Pruning fuel & $\begin{array}{r}1.851 \\
\$ 4\end{array}$ & $\begin{array}{l}\times \mathrm{gal} / \mathrm{h} \times \\
1\end{array}$ & 7.40 \\
\hline Thinning fuel & $\begin{array}{r}0.9 \mathrm{~h} / \\
\$ 4\end{array}$ & $1 \mathrm{gal} / \mathrm{h} \times$ & 3.60 \\
\hline
\end{tabular}

Total

81.54

${ }^{2} \mathrm{HP}=$ hand pruned to $36-40$ buds, $\mathrm{MP}+\mathrm{HT}=$ mechanically prepruned to an 8 -inch $(20.4 \mathrm{~cm})$ bearing surface, hand shoot thinning conducted at Eichhorn-Lorenz scale (Coombe, 1995) stage 17 to retain similar number of shoots as $\mathrm{HP}, \mathrm{MP}+\mathrm{MT}=$ mechanically box-pruned to a 4 -inch $(10.2 \mathrm{~cm})$ bearing surface, mechanical shoot thinning conducted at Eichhorn-Lorenz scale stage 17 to retain similar number of shoots as HP.

${ }^{y} 1 \mathrm{~h} / \mathrm{acre}=2.4711 \mathrm{~h} / \mathrm{ha}, \$ 1.00 / \mathrm{acre}=\$ 2.471 \mathrm{l} / \mathrm{ha}, 1 \mathrm{gal}=3.7854 \mathrm{~L}, \$ 1.00 / \mathrm{gal}=\$ 0.2642 / \mathrm{L}$.

Implementing mechanization as part of the canopy management practices reduced labor costs in this study. In the SJV of California, all canopy management methods tested in this study are used with varying degrees of success. Verdagaal et al. (2008) reported $44.5 \%$ of the labor operation time of $90.35 \mathrm{~h}$ per acre in a 'Cabernet Sauvignon' was due to manual application of canopy management practices. Our results from the HP treatment are consistent with this report, where $40 \%$ of labor operation time was attributed to canopy management. Implementing the $\mathrm{MP}+\mathrm{HT}$ treatment reduced the labor operation time requirement by $66 \%$, whereas the $\mathrm{MP}+\mathrm{MT}$ treatment reduced it by $87 \%$, compared with HP treatment (Table 5). Bates and Morris (2009) recommended that 'Concord' in the cool growing regions of western New York be managed with mechanical pruning and a $\mathrm{HP}$ /thinning follow-up because of the short season, the slow accumulation of juice soluble solids, and the difficulty to balance the vines in absence of mechanical shoot thinning. In contrast, our results indicate the $\mathrm{MP}+\mathrm{MT}$ treatment may be used without any adverse effects on vine balance as indicated by the amicable Ravaz index achieved and lack of treatment differences on fruit composition and berry skin phenolics in a warm climate.

\section{Conclusions}

The canopy management methods tested in this study are used commercially in the SJV of California with varying degrees of success. There are cost savings associated with implementing canopy management mechanization whether just mechanizing the dormant pruning or combining it with mechanical shoot thinning to achieve vine balance. The MP+MT treatment reduced the labor operation time and the labor costs. The use of mechanical box-pruning and mechanical shoot thinning provides a viable labor cost savings of $80 \%$ compared with conventional HP of 'Cabernet Sauvignon' grapevine without any adverse effects on canopy architecture and microclimate, fruit composition, berry phenolics, and balanced vines for sustained production in a warm climate.

\section{Literature cited}

Bates, T. and J. Morris. 2009. Mechanical cane pruning and crop adjustment decreases labor costs maintains fruit quality in New York 'Concord' grape vineyards. HortTechnology 19:247-253.

California Department of Food and Agriculture. 2012. Grape crush report Final 2011. I Apr. 2012. <http://www.nass. usda.gov/Statistics_by_State/California>.

Coombe, B.C. 1995. Adoption of a system for identifying grapevine growth stages. Aust. J. Grape Wine Res. 1:104110.

Dokoozlian, N.K. and W.M. Kliewer. 1995. The light environment within grapevine canopies I. Description and seasonal changes during fruit environment. Amer. J. Enol. Viticult. 46:209218.

Flaherty, D.I., D.I. Christensen, and T. Lanni. 1992. Grape pest management. Univ. of California Agr. Natural Resources. Bul. 3343.

Giusti, M.M. and R.E. Wrolstad. 2001. Characterization and measurement of anthocyanins by UV-visible spectroscopy, p. F1.2.1-F1.2.13. In: R.W. Wrolstad (ed.). Current protocols in food analytical chemistry. Wiley, New York.

Gladstone, E.A. and N.K. Dokoozlian. 2003. Influence of leaf area density and trellis/training systems on the microclimate within grapevine canopies. Vitis 42:123-131.

Harbertson, J.F., E.A. Picciotto, and D.O. Adams. 2003. Measurement of polymeric pigments in grape berry extract and wines using a protein precipitation assay combined with bisulfate bleaching. Amer. J. Enol. Viticult. 54:301-306.

Hagerman, A.E. and L.G. Butler. 1978. Protein precipitation method for the quantitative determination of tannins. J. Agr. Food Chem. 26:809-812. 
Keller, M. 2010. The science of grapevines: Anatomy and physiology. Academic Press, Burlington, MA.

Keller, M., R.P. Smithyman, and L.J. Mills. 2008. Interactive effects of deficit irrigation and Cabernet Sauvignon grapevines in an arid climate. Amer. J. Enol. Viticult. 59:221-233.

Kliewer, W.M. and N.K. Dokoozlian. 2005. Leaf area/crop weight ratios of grapevines: Influence of fruit composition and wine quality. Amer. J. Enol. Viticult. 56:170-181.

Kurtural, S.K., B.H. Taylor, and I.E. Dami. 2006. Effects of pruning and cluster thinning on yield and fruit composition of "Chambourcin" grapevines. HortTechnology 16:233-240.

Kurtural, S.K and S.B. O'Daniel. 2008. Crop estimation in vineyards. Univ. of Kentucky Coop. Ext. Serv. Bul. HO-86.

Levene, H. 1960. Contributions to probability and statistics. Stanford University Press, Palo Alto, CA.

Morris, J.R. 2007. Development and commercialization of a complete vineyard mechanization system. HortTechnology 17:411-420.

Petrie, P.R. and P. Clingeleffer. 2006. Crop thinning, grape maturity and anthocyanins concentration: Outcomes from irrigated Cabernet Sauvignon in a warm climate. Aust. J. Grape Wine Res. 12:2129.

Reynolds, A.G. and D. Wardle. 1993. Yield component path analysis of Okanagan Riesling vines conventionally pruned or subjected to simulated mechanical pruning. Amer. J. Enol. Viticult. 44:173-179.

Smart, R.E. 1985. Principles of grapevine microclimate manipulations with implications for yield and quality: A review. Amer. J. Enol. Viticult. 36:230-239.

Smart, R.E. 1988. Shoot spacing and canopy microclimate. Amer. J. Enol. Viticult. 39:325-333.

Smart, R.E. and M. Robinson. 1991. Sunlight into wine: A handbook for winegrape canopy management. Winetitles, Adelaide, Australia.
Terry, D.B. and S.K. Kurtural. 2011. Achieving vine balance of Syrah with mechanical canopy management and regulated deficit irrigation. Amer. J. Enol. Viticult. 62:426-437.

U. S. Department of Agriculture. 2011. Soil survey staff Official soil series descriptions. 1 Apr. 2011. <http://soils.usda. gov/technical/classification/osd/ index.html>.

Verdagaal, P., K.M. Klonsky, and R.L. De Moura. 2008. Sample costs to establish a vineyard and produce winegrapes 'Cabernet Sauvignon' Crush District 11 of San Joaquin and Sacramento counties. Univ. of California Coop. Ext. Serv. Bul. GR-VN08.

Waterhouse, A. 2002. Determination of total phenolics, p. 11.1.1-11.1.8. In: R.W. Wrolstad (ed.). Current protocols in food analytical chemistry. Wiley, New York.

Zabadal, T.J., G.R. Vanee, T.W. Dittmer, and R.L. Ledebuhr. 2002. Evaluation of strategies for pruning and crop control of Concord grapevines in southwest Michigan. Amer. J. Enol. Viticult. 53:204-209. 